\title{
Increasing the Accuracy of Free-Form Surface Multiaxis Milling
}

\author{
Marek Sadílek ${ }^{1, *}$, Zdeněk Poruba $^{2}$, Lenka Čepová $^{1}$ and Michal Šajgalík ${ }^{3}$ (i) \\ 1 Department of Machining and Assembly, Faculty of Mechanical Engineering, VŠB-Technical University \\ of Ostrava, 70833 Ostrava, Czech Republic; lenka.cepova@vsb.cz \\ 2 Department of Applied Mechanics, Faculty of Mechanical Engineering, VŠB-Technical University of Ostrava, \\ 70833 Ostrava, Czech Republic; zdenek.poruba@vsb.cz \\ 3 Department of Machining and Production Technologies, University of Zilina, 01026 Zilina, Slovakia; \\ michal.sajgalik@fstroj.uniza.sk \\ * Correspondence: marek.sadilek@vsb.cz; Tel.: +420-605-239-835
}

\section{check for}

updates

Citation: Sadílek, M.; Poruba, Z.; Čepová, L.; Šajgalík, M. Increasing the Accuracy of Free-Form Surface Multiaxis Milling. Materials 2021, 14, 25. https://dx.doi.org/10.3390/ ma14010025

Received: 2 November 2020 Accepted: 18 December 2020 Published: 23 December 2020

Publisher's Note: MDPI stays neutral with regard to jurisdictional claims in published maps and institutional affiliations.

Copyright: () 2020 by the authors. Licensee MDPI, Basel, Switzerland. This article is an open access article distributed under the terms and conditions of the Creative Commons Attribution (CC BY) license (https: / / creativecommons.org/ licenses/by/4.0/).

\begin{abstract}
This contribution deals with the accuracy of machining during free-form surface milling using various technologies. The contribution analyzes the accuracy and surface roughness of machined experimental samples using 3-axis, $3+2$-axis, and 5-axis milling. Experimentation is focusing on the tool axis inclination angle-it is the position of the tool axis relative to the workpiece. When comparing machining accuracy during 3-axis, $3+2$-axis, and 5-axis milling the highest accuracy (deviation ranging from 0 to $17 \mu \mathrm{m}$ ) was achieved with 5-axis simultaneous milling (inclination angles $\beta_{\mathrm{f}}=10$ to $15^{\circ}, \beta_{\mathrm{n}}=10$ to $15^{\circ}$ ). This contribution is also enriched by comparing a CAD (Computer Aided Design) model with the prediction of milled surface errors in the CAM (Computer Aided Manufacturing) system. This allows us to determine the size of the deviations of the calculated surfaces before the machining process. This prediction is analyzed with real measured deviations on a shaped surface- using optical three-dimensional microscope Alicona Infinite Focus G5.
\end{abstract}

Keywords: multi axis milling; 5-axis milling; accuracy; CAM system

\section{Introduction}

In Figure 1 there is a schematic diagram of the aspects that should be monitored when comparing the machining process during 3-axis and multiaxis milling.

The tool axis inclination against a workpiece has a significant influence on the size and direction of the cutting forces [1,2] (it means the individual cutting force components). The radial, axial, and tangential cutting forces tend to push the tool apart. It is, therefore, appropriate to verify to what extent the proposed changes in the tool axis inclination angle affect the accuracy of the machined surface.

Studies on optimizing the cutting conditions and their influence on cutting forces are described in [3-7]. Studies on machined surface topography while changing the orientations of the tool axis can be found in the literature [8-14]. Studies on the contact of the tool with the workpiece are described in $[3,7,13]$. The deformation deflection of the cutting tools or the deformation of the machined parts are mentioned in $[1,8,14,15]$. The problem of the durability of the cutting tool is described in the literature [16-18]. Shape and chip geometry is described in the literature [3,4].

In the literature $[19,20]$, errors caused by cutter deflection when machining a sculptured part using a ball-end milling tool are described. In the literature [20], a flexible model for estimating the form error in three-axis ball-end milling of the sculptured surface can be found.

Using multiaxis machining $(3+2$ - and 5 -axis machining) includes these benefits, which is based on previous research by the authors [2,14,21-24]:

- increasing milling accuracy is proved in this article,

- decreasing surface roughness in the pick feed direction and the feed direction, 
- decreasing the cutting time (using a bigger ae, fz with the same surface roughness),

- constant cross-sectional area of the chip,

- increasing durability (tool life) of the cutting tool,

- constant cutting conditions can be used and cutting speed can be increased,

- decreasing the size of the cutting forces components,

- a favorable orientation of cutting force direction,

- increasing the functional surface properties of the machined surface,

- decreasing of the cutting temperature and inhibition of the self-excited oscillations.

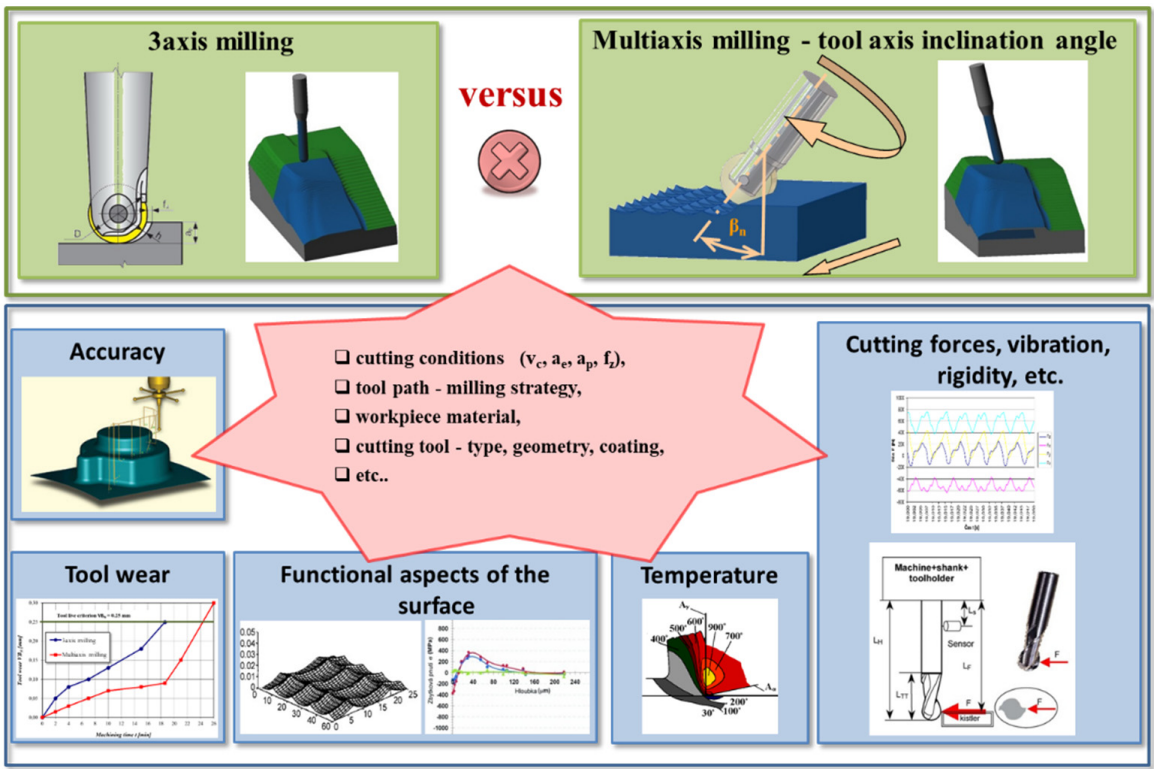

Figure 1. Aspects of the machining process.

\section{Kinematics of the Milling Strategy}

The problem of 3-axis and multi-axis milling with reference to the kinematics and position of the tool axis of the milling cutter is described in the author's articles [2,14,22], see Figure 2.

The possibilities of tool inclination towards a normal surface are shown in Figure 2.

There are two ways that can be used for an inclination in the feed direction (see Figure 3) as well as for an inclination that is perpendicular to the feed direction, see Figure $4[2,14]$.

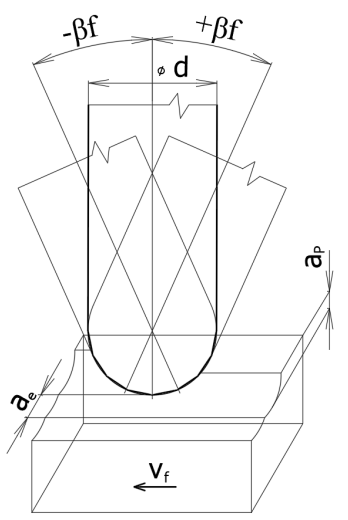

(a)

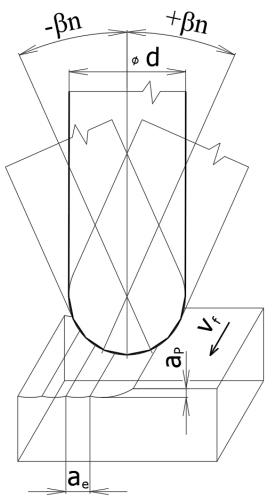

(b)

Figure 2. The possibilities of the milling strategy with a tool axis inclination angle [2,14]. (a) Tilt in feed direction, (b) tilt in pick feed direction ( $\mathrm{d}$ - tool diameter, $\mathrm{a}_{\mathrm{p}}$ - axial depth of cut, $\mathrm{a}_{\mathrm{e}}$-radial depth of cut, $\mathrm{v}_{\mathrm{f}}$ - feed direction, $\beta_{\mathrm{f}}$-tool axis inclination angle in the feed direction, $\beta_{\mathrm{n}}$-tool axis inclination angle in the pick feed direction). 


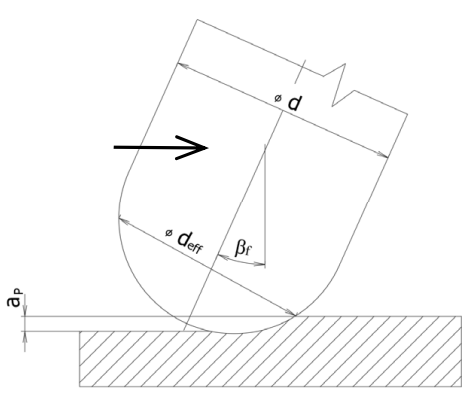

(a)

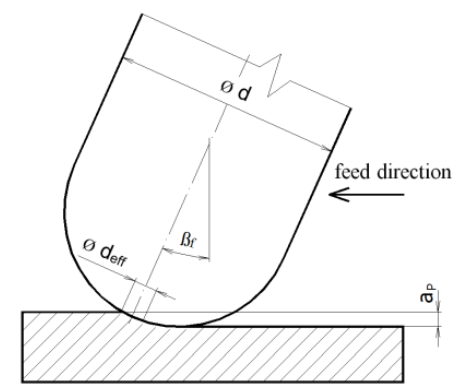

(b)

Figure 3. Tool axis inclination angle $\beta_{\mathrm{f}}$ in feed direction $[2,14]$ (a) pulled tool (b) pushed tool (d-tool diameter, $\mathrm{d}_{\mathrm{eff}}$ - effective tool diameter, $\mathrm{a}_{\mathrm{p}}$-axial depth of cut).

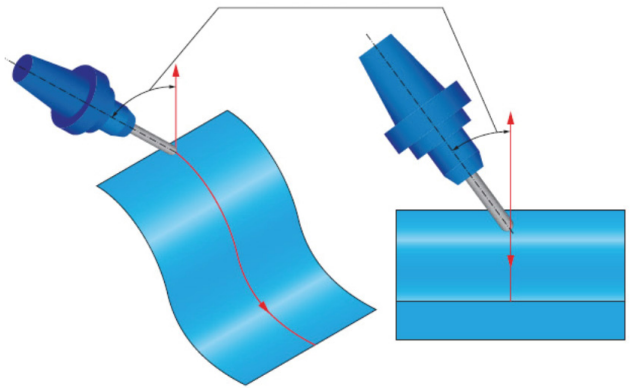

(a)

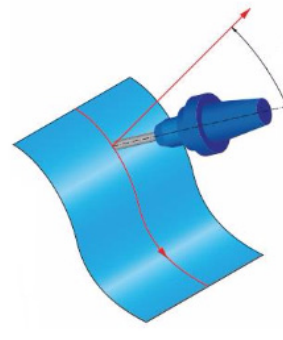

(b)

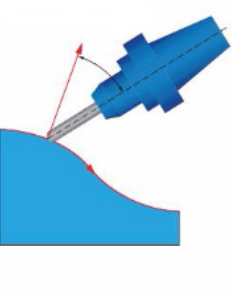

Figure 4. Tool axis inclination angle in both directions (a) Tool axis inclination angle in pick feed direction $\beta_{\mathrm{n}}(\mathbf{b})$ Tool axis inclination angle in feed direction $\beta_{\mathrm{f}}$.

The literature $[14,22,25]$ shows how changing the tilting of the tool affects the effective cutter diameter and then the effective cutting speed.

The scientific literature describes using the tool axis inclination angle at the range from 10 to $30^{\circ}$. Another scientific paper uses both inclination angles at $15^{\circ}$. References [8,9] recommend a range from 10 to $20^{\circ}$.

\section{Experimental Work}

The experimental part describes the machined accuracy after machining with different positions of the tool axis. It means a tool axis relative to the normal surface. The original CAD model was created in CAM system Inventor.

The dimensions of the model (see Figure 5) were designed with regard to the use of the finishing tool (a $6 \mathrm{~mm}$ diameter ball-end milling cutter) and its subsequent effective measurement on the measuring instrument.

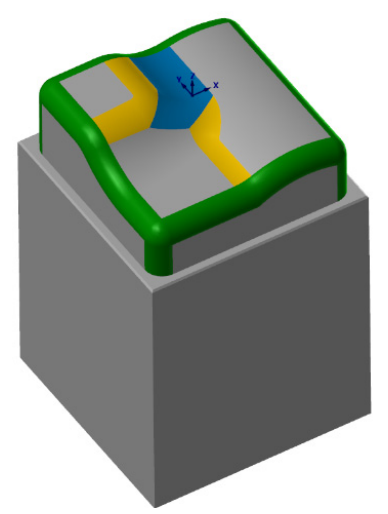

Figure 5. CAD geometry used in experiments (Surfaces: $\mathrm{R} 2 \mathrm{~mm}$-green, $\mathrm{R} 5 \mathrm{~mm}$-yellow, R6 mm -blue). 
The experiment consists of three parts, see Figure 6:

(a) 3-axis milling-the tool axis inclination angles are $\beta_{\mathrm{f}}=0^{\circ}, \beta_{\mathrm{n}}=0^{\circ}$, i.e., without changing the tool axis angle relative to the workpiece. It consists of one sample.

(b) $3+2$-axis milling - constant tilt relative to the orientation of the surfaces, $\beta_{\mathrm{f}}$-pulled tool, $\beta_{\mathrm{n}}$-tilt in pick feed direction. It consists of 24 samples.

(c) 5-axis-simultaneous movement $(X, Y, Z, B, C)$, tool axis inclination angles follow the orientation of the surface- the slope of the tool axis, versus the normal to the surface, varies depending on the shape of the model surface. It consists of 25 samples.

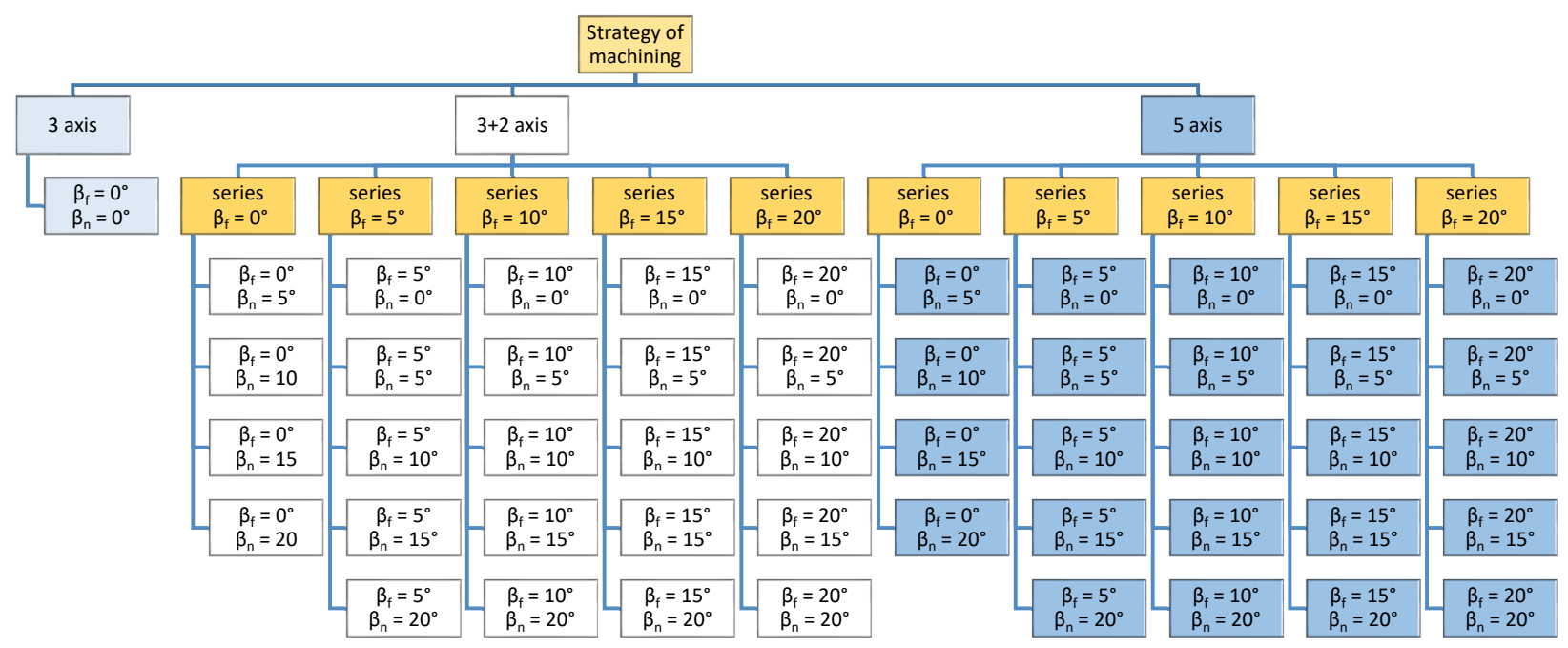

Figure 6. Chart of milling samples.

Each sample of these three parts (each setup) was machined and measured three times, but we are presenting only representative samples.

In the experiment, $3+2$-axis machining is 3 -axis machining with fixed toll axis orientation. Simultaneous 5-axis machining moves the cutting tool on the $\mathrm{x}, \mathrm{y}$, and $\mathrm{z}$ axes and rotates the $\mathrm{A}, \mathrm{B}$, and $\mathrm{C}$ axes (in our kinematic $\mathrm{B}$ and $\mathrm{C}$ axes) to maintain continuous contact between the tool and workpiece, unlike $3+2$-axis machining, where the part is in a fixed orientation.

Five positions (tilts) of the tool in the feed direction and five positions in the pick feed direction were analyzed. Changing the orientation of the axis in the feed direction by $\beta_{\mathrm{f}}=0^{\circ}$ to $\beta_{\mathrm{f}}=20^{\circ}$ was partitioned at $5^{\circ}$. Changing the orientation of the axis in the pick feed direction by $\beta_{n}=0^{\circ}$ to $\beta_{n}=20^{\circ}$ was partitioned at $5^{\circ}$. Maximum inclination angle was set according to the shallow surfaces of the sample. Each sample has a size of $40 \mathrm{~mm}$ $\times 40 \mathrm{~mm} \times 25 \mathrm{~mm}$. In the experiments, a 5-axis milling machine was used.

The technological parameters of the cutting process were adopted as a constant for each of the machined samples (see Tables 1 and 2).

Specified cutting conditions and their relationships are shown in Figure 7.

It is important to note that a cycle was used (in the Heidenhain control system) with a tolerance $0.01 \mathrm{~mm}$, which affects the machining accuracy, surface roughness, and feed rate. Cycle 32 was used, including a tolerance TA for rotation axes in the control system Heidenhain iTNC 530:

- CYCL DEF 32.0 TOLERANCE (using special cycles in Heidenhain iTNC),

- CYCL DEF $32.1 \mathrm{~T} 0.01$ (the tolerance was set at $0.01 \mathrm{~mm}$ ),

- CYCL DEF 32.2 HSC-MODE:1 TA1 (MODE: 1 means for finishing, a permissible deviation of the position of the rotary axes $\mathrm{TA}=1^{\circ}$ ).

It is suitable to use CYCL DEF 32.0 TOLERANCE during 5-axis simultaneous machining, including a tolerance for rotary axes TA. TA is the permissible deviation of the position 
of the rotary axes with an active M128. The TNC reduces the feed in such a way that the slowest axis travels as a maximum feed (during multiaxis machining). Rotational axes are usually slower than linear axes. By setting a larger tolerance (for example, $\mathrm{TA}=10^{\circ}$ ) the machining time for multi-axis machining can be considerably decreased because the TNC does not always need to travel the rotary axis to the preset target position. The contour does not interfere with setting this tolerance $\left(1^{\circ}\right)$ of the rotary axes. Only the position of the rotary axis to the workpiece surface is changed (ranging $1^{\circ}$ ).

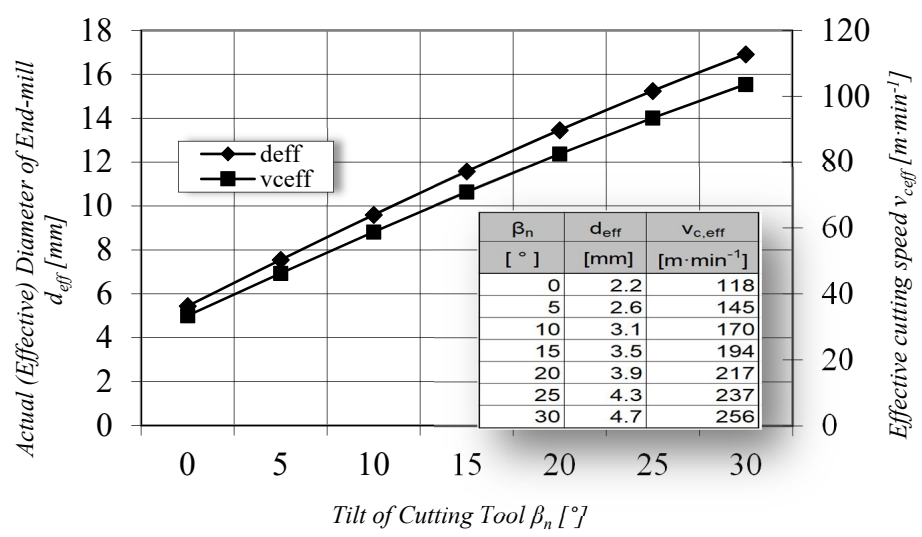

Figure 7. The dependence of the effective cutting speed $v_{\text {ceff }}$ and the effective tool diameter $d_{\text {eff }}$ at the tool axis inclination angle $\beta_{\mathrm{n}},\left(\mathrm{d}=6 \mathrm{~mm}, \mathrm{a}_{\mathrm{p}}=0.2 \mathrm{~mm}, \mathrm{v}_{\mathrm{c}}=330 \mathrm{~m} \cdot \mathrm{min}^{-1}, \mathrm{n}=17,500 \mathrm{~min}^{-1}\right)$.

Table 1. Technological parameters of the cutting process.

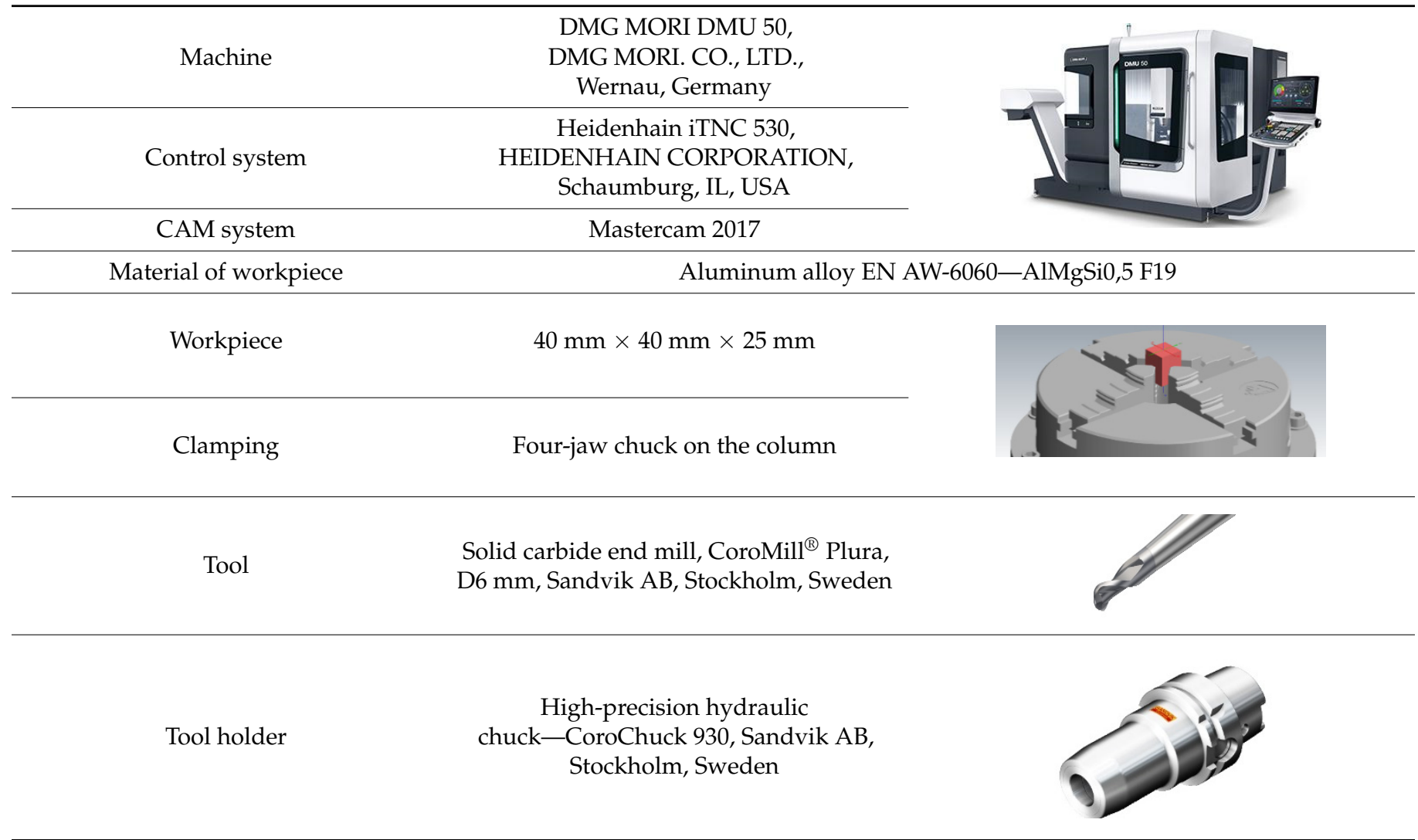


Table 2. Cutting conditions of finishing operation.

\begin{tabular}{|c|c|c|c|c|c|c|c|}
\hline $\begin{array}{l}\text { Ball Endmill } \\
\text { Diameter }\end{array}$ & Spindle rev. & $\begin{array}{l}\text { Cutting } \\
\text { Speed }\end{array}$ & $\begin{array}{l}\text { Axial } \\
\text { Cutting } \\
\text { Depth }\end{array}$ & $\begin{array}{l}\text { Radial } \\
\text { Cutting } \\
\text { Depth }\end{array}$ & $\begin{array}{l}\text { Feed Per } \\
\text { Tooth }\end{array}$ & Feed & $\begin{array}{l}\text { Plunge and } \\
\text { Retract Feed }\end{array}$ \\
\hline $\mathrm{d}$ & $\mathrm{n}$ & $\mathrm{v}_{\mathrm{c}}$ & $a_{p}$ & $a_{e}$ & $f_{z}$ & $\mathrm{f}$ & $\mathrm{f}_{\mathrm{p}}, \mathrm{f}_{\mathrm{r}}$ \\
\hline$[\mathrm{mm}]$ & {$\left[\min ^{-1}\right]$} & {$\left[\mathrm{m} \cdot \mathrm{min}^{-1}\right]$} & {$[\mathrm{mm}]$} & {$[\mathrm{mm}]$} & {$[\mathrm{mm}]$} & {$\left[\mathrm{mm} \cdot \mathrm{min}^{-1}\right]$} & {$\left[\mathrm{mm} \cdot \mathrm{min}^{-1}\right]$} \\
\hline 6 & 17,500 & 330 & 0.2 & 0.08 & 0.08 & 2800 & 1910 \\
\hline & Colling & & \multicolumn{5}{|c|}{ Blasocut 2000 CF, Art. 875-12 } \\
\hline & Strategy & & \multicolumn{5}{|c|}{$\begin{array}{l}\text { - tool path "zig zag", } \\
\text { - } \quad \text { conventional milling and climb milling combination, } \\
\text { the tool axis inclination angle in both directions-feed direction } \beta_{\mathrm{f}} \text { and pick } \\
\text { feed direction } \beta_{\mathrm{n}} \text {-called in practice the "pulled tool". }\end{array}$} \\
\hline
\end{tabular}

\subsection{Accuracy Measurement}

Machined sample measurements were carried out with an optical three-dimensional microscope Alicona Infinite Focus G5, (Alicona Imaging GmbH, Raaba/Graz, Austria), see Figure 8 . The optical 3D micro coordinate measurement system is suitable for accuracy and surface roughness measurements.

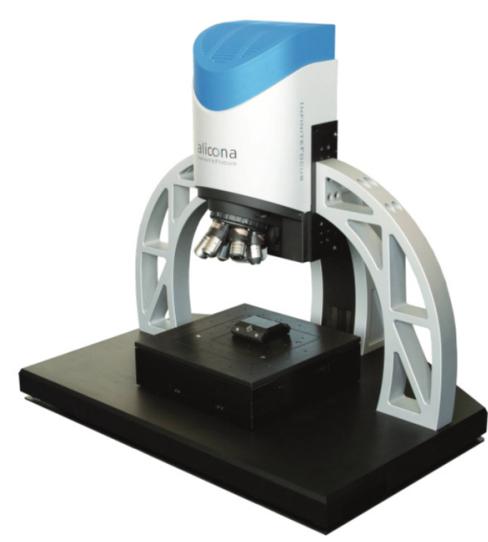

(a)

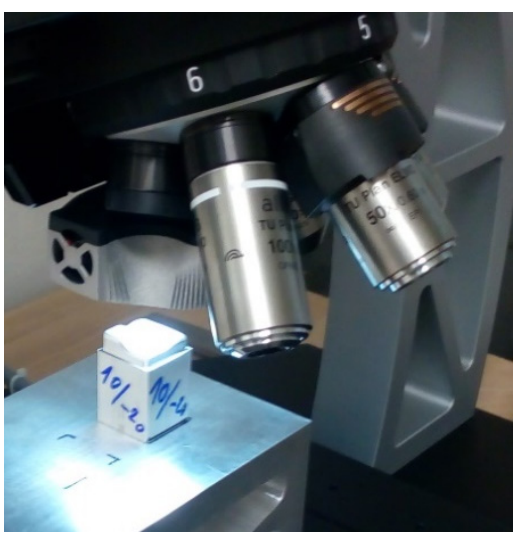

(b)

Figure 8. 3D micro coordinate measurement system (a) Alicona Infinite Focus G5 (b) sample for measurement.

The samples measured using this device were compared to the default model created in the CAD system Inventor. These real surfaces were also compared with the predicted surfaces calculated in the CAM system Mastercam. The models were saved with the input format necessary for Alicona Infinite Focus G5 (software IF MeasureSuite, Alicona Imaging $\mathrm{GmbH}$, Raaba/Graz, Austria) in the format *. stl with a tolerance of $0.0001 \mathrm{~mm}$ (so as not to affect the measurement results).

Real machined surface is presented in Figure 9.

The accuracy comparison was mainly focused on the problematic radius crossing of surfaces at the area of the center of the workpiece. Inaccuracies were found mostly at this area in 3-axis and $3+2$-axis milling.

A range of the variance scale was selected at -50 to $+50 \mu \mathrm{m}$ for all samples. Machined surfaces colored light green have minimal deviations (range of 10 to $20 \mu \mathrm{m}$ ), see Figure 10. A range from 20 to $40 \mu \mathrm{m}$ deviations is in the central area of the workpiece. 


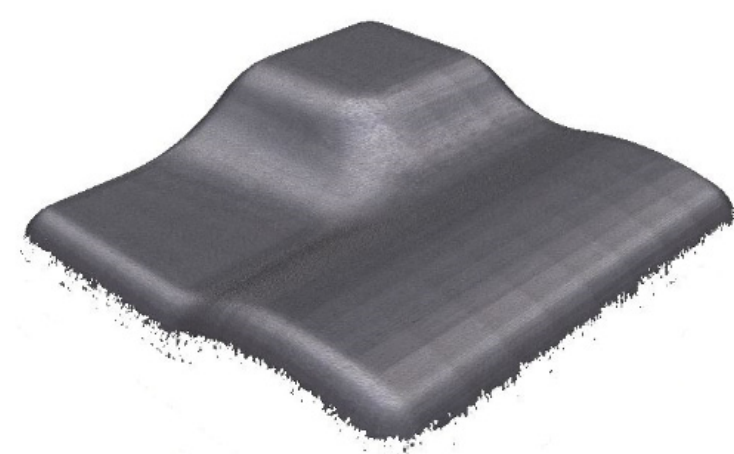

(a)

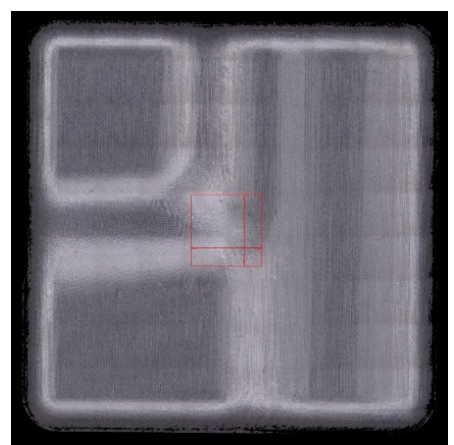

(b)

Figure 9. An example of the result of the scanned surface of a single sample on a Alicona Infinite Focus G5 (a) $3+2$ milling, tool axis inclinations $\beta_{\mathrm{f}}=5^{\circ}, \beta_{\mathrm{n}}=10^{\circ}$, (b) red square area $(4 \mathrm{~mm} \times 4 \mathrm{~mm})$ for surface roughness measurement.

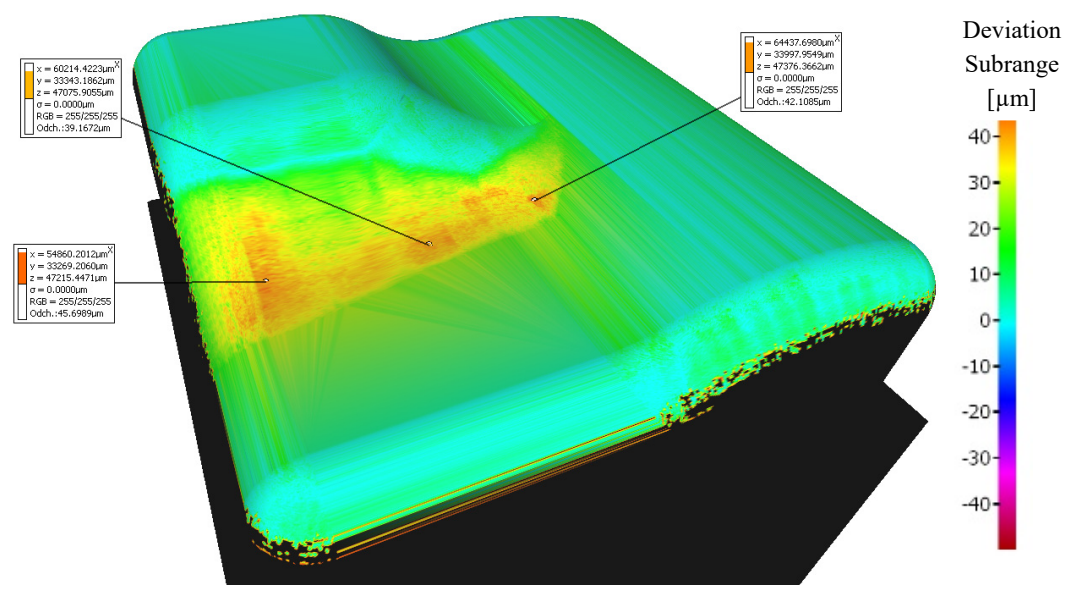

Figure 10. Comparison of the initial model with the workpiece after 3-axis milling (without tool axis inclination: $\left.\beta_{\mathrm{f}}=0^{\circ}, \beta_{\mathrm{n}}=0^{\circ}\right)$.

The sample machined with a $3+2$-axis milling with a tool inclination $\beta_{\mathrm{f}}=20^{\circ}, \beta_{\mathrm{n}}=0^{\circ}$ shows the best machining results from the 3 -axis and $3+2$-axis milling group of samples, see Figure 11. Deviations 0 to $20 \mu \mathrm{m}$ were achieved at the center of the workpiece.

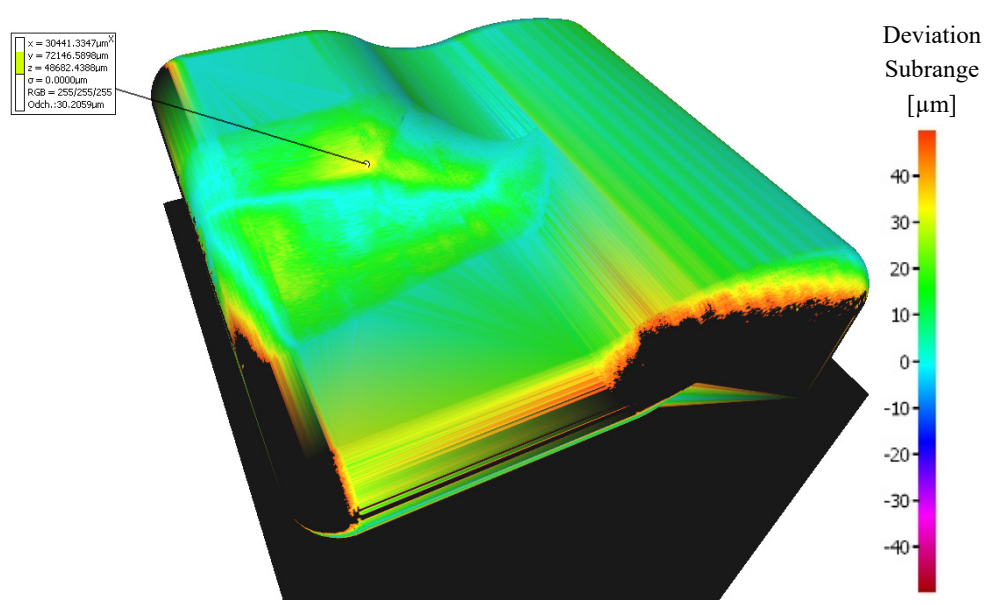

Figure 11. Comparison of the initial model with the workpiece after $3+2$-axis milling (tool axis inclination: $\beta_{\mathrm{f}}=20^{\circ}, \beta_{\mathrm{n}}=0^{\circ}$ ). 
The sample machined with a $3+2$-axis milling with a tool inclination $\beta_{\mathrm{f}}=10^{\circ}$, $\beta_{\mathrm{n}}=20^{\circ}$ shows the worst machining results, see Figure 12 . Deviations in the center of the workpiece reach values higher than the upper limit of the selected range of $50 \mu \mathrm{m}$.

By using simultaneous 5-axis milling, the machining accuracy of all samples was improved. The problematic area in the center of the samples is more accurately machined by simultaneous 5 -axis milling compared to 3 -axis and $3+2$-axis milling, where deviations are significantly unsymmetrically changing.
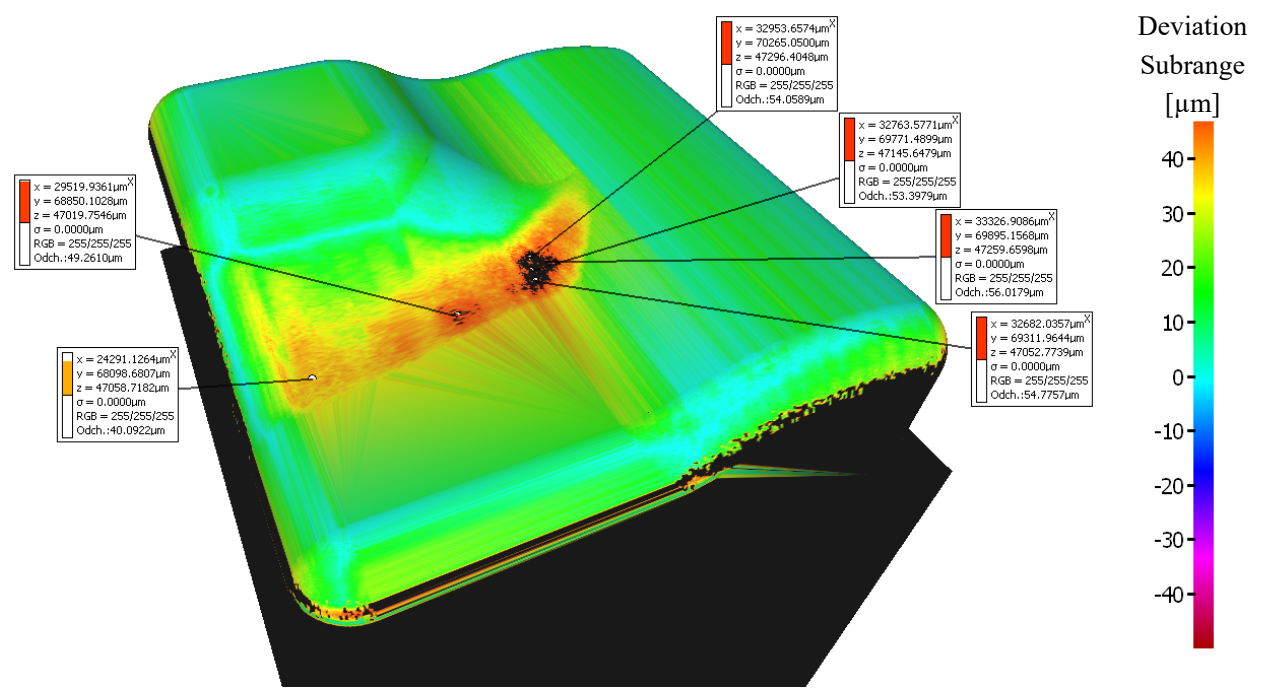

Figure 12. Comparison of the initial model with the workpiece after $3+2$-axis milling (tool inclination $\left.\beta_{\mathrm{f}}=10^{\circ}, \beta_{\mathrm{n}}=20^{\circ}\right)$.

The sample machined using a 5-axis milling with a tool inclination $\beta_{\mathrm{f}}=0^{\circ}, \beta_{\mathrm{n}}=10^{\circ}$ shows the best machining results from all groups (3-axis, $3+2$-axis, and 5 -axis milling), see Figure 13. A deviation ranging from 0 to $17 \mu \mathrm{m}$ was measured at the center of the workpiece.
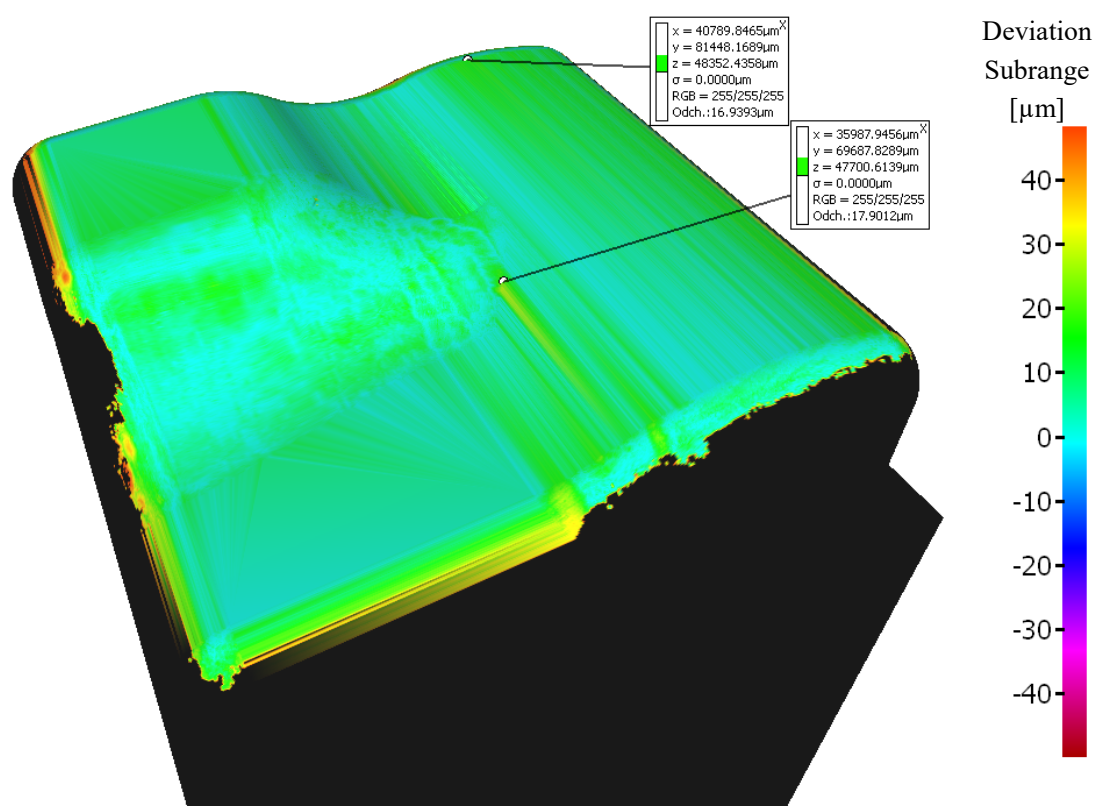

Figure 13. Comparison of the initial model with the workpiece after 5-axis milling (tool inclination $\left.\beta_{\mathrm{f}}=0^{\circ}, \beta_{\mathrm{n}}=10^{\circ}\right)$.

The deviations were measured at a different area during the 5-axis milling compared to the 3-axis and 3 + 2-axis milling, see Figure 14 (area A marked on the model). The size of 
the deviations in this area (a slight convex curvature on the right side of the sample-area A marked on the model) differs for each 5-axis machining, see Figure 13. This phenomenon has not been observed during $3+2$-axis milling.
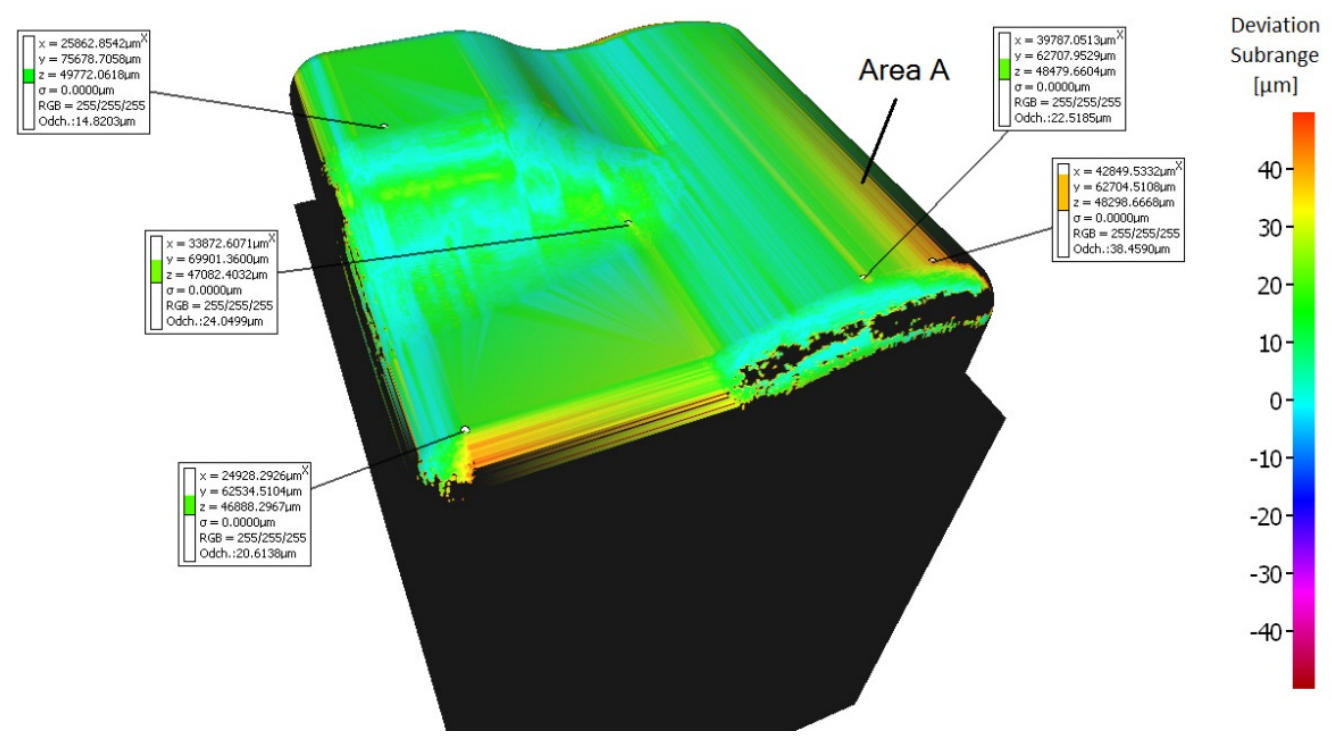

Figure 14. Comparison of the initial model with the workpiece after 5-axis milling (tool inclination $\left.\beta_{\mathrm{f}}=15^{\circ}, \beta_{\mathrm{n}}=5^{\circ}\right)$.

\subsection{The Prediction of Milled Surface Errors in the CAM System}

The CAM system allows comparing the CAD model with the prediction of milled surface errors. This allows determining the size of errors of the calculated surfaces before machining. A tolerance was set at $0.001 \mathrm{~mm}$ (path tolerance, part tolerance, tool shape tolerance). Figure 15 shows the verification procedure of the machining accuracy.

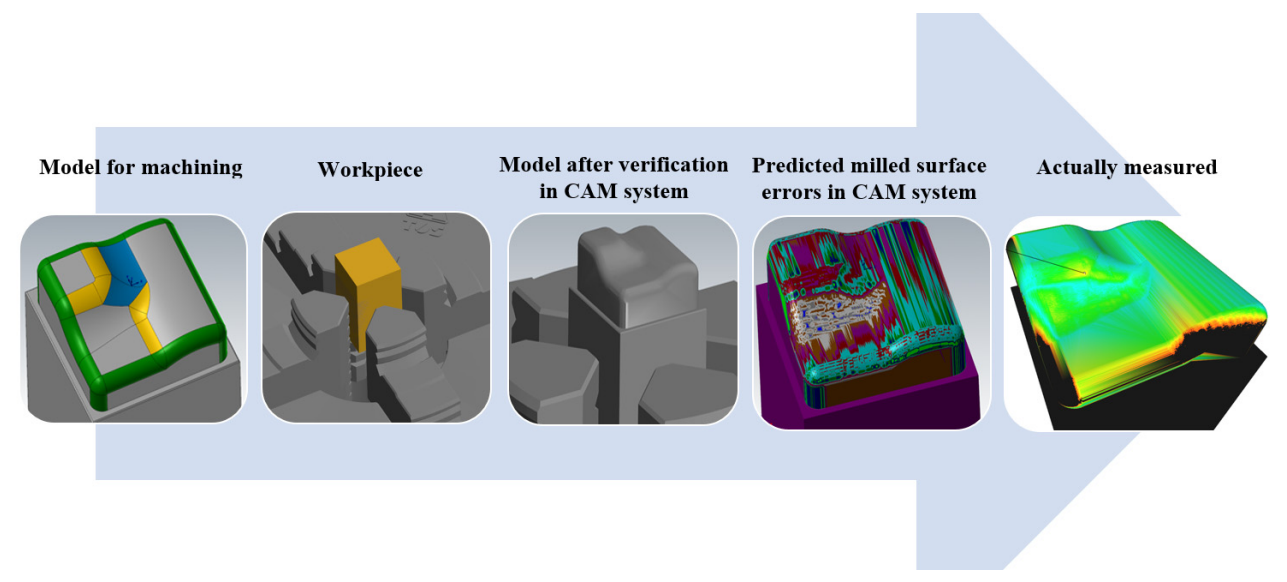

Figure 15. Diagram of the verification procedure of the machining accuracy.

Figure 16 shows a comparison of a CAD model (made in the CAD system) and the prediction of milled surface errors using 3-axis milling in the CAM system-Mastercam. When comparing the prediction of milled surface errors after a 3-axis milling in the CAM system, see Figure 16, and the measurement result on the Alicona, see Figure 10, a conformity can be seen in the problematic area in the center of the sample (the predicted deviations of accuracy are 20 to $40 \mu \mathrm{m}$ ). 


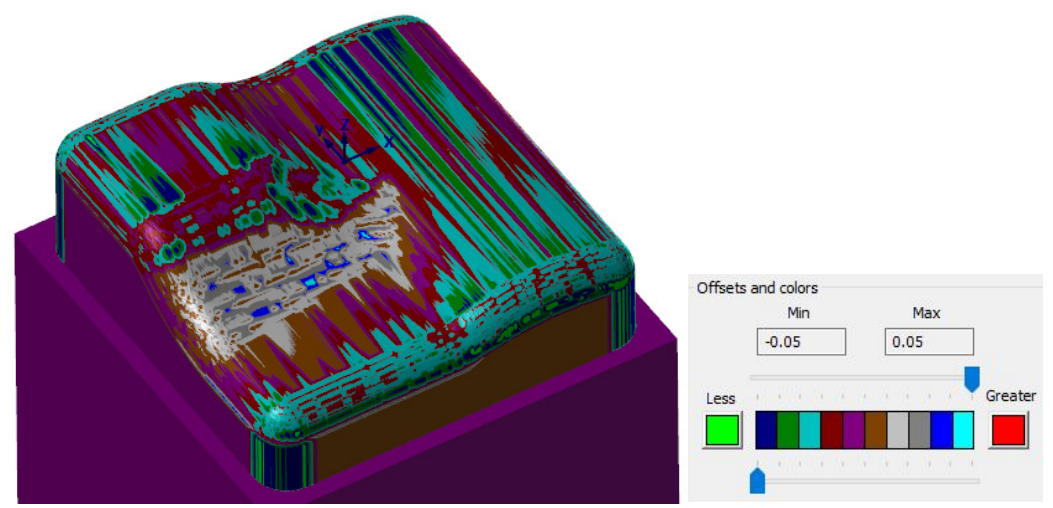

Figure 16. Comparison of CAD model (Inventor) and prediction of milled surface errors using 3-axis milling (Mastercam).

Figure 17 shows two comparisons of the CAD model from Inventor and a prediction of milled surface errors using a $3+2$-axis milling in the CAM system.

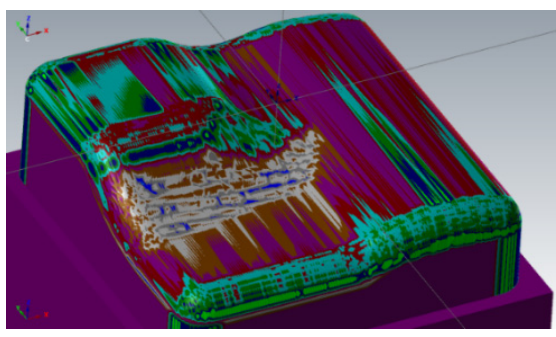

(a)
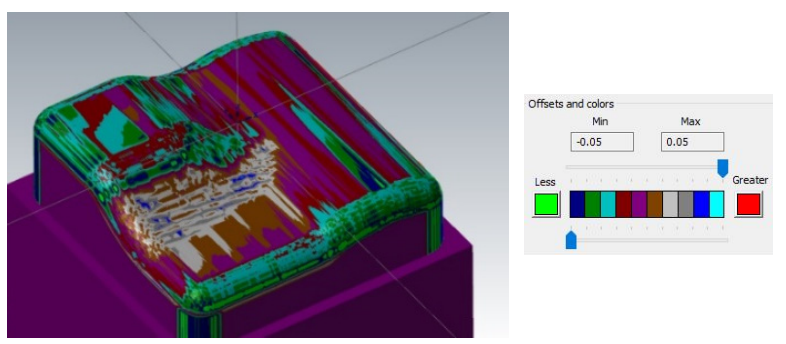

(b)

Figure 17. Comparison of the CAD model (Inventor) and the prediction of milled surface errors using $3+2$-axis milling (Mastercam), (a) tool inclination $\beta_{\mathrm{f}}=20^{\circ}, \beta_{\mathrm{n}}=0^{\circ}$, (b) tool inclination $\beta_{\mathrm{f}}=10^{\circ}$, $\left.\beta_{\mathrm{n}}=20^{\circ}\right)$.

During changing the tool axis inclination angle $(3+2$-axis milling), the calculated shape of machined surfaces in the CAM system does not change significantly, see Figure 18. The individual tilts have very little effect on the shape of the calculated workpiece in the CAM system.

There is a similar result when comparing the calculated residual material in the CAM system and the real results of the measurement in the problematic area of the center of the sample, see Figure 18. The prediction of the formation of a planar surface (on the left of the sample) in the CAM system Mastercam does not correspond to the actually measured results. This prediction of $3+2$ milling before the real process is not conclusive in practice. This comparison is, therefore, rather indicative.

Figure 19 shows a comparison of the CAD model and the prediction of milled surface errors using a 5-axis milling in the CAM system. These errors are 0 to $15 \mu \mathrm{m}$.

There are very similar results on all surfaces when comparing the predicted milled surface errors and the real errors using 5-axis milling. 5-axis milling has the highest consistency of the predicted errors with the measured errors. 


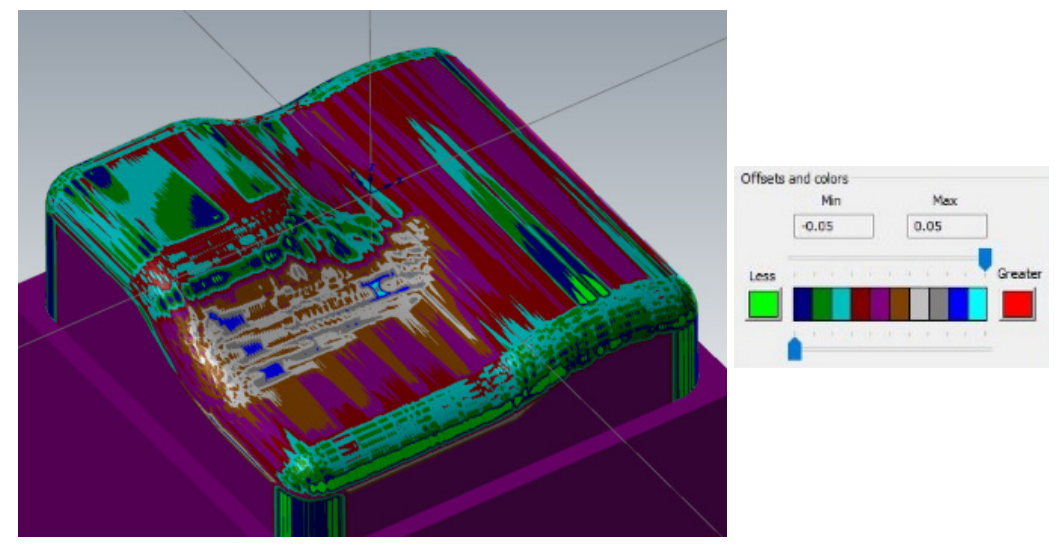

(a)
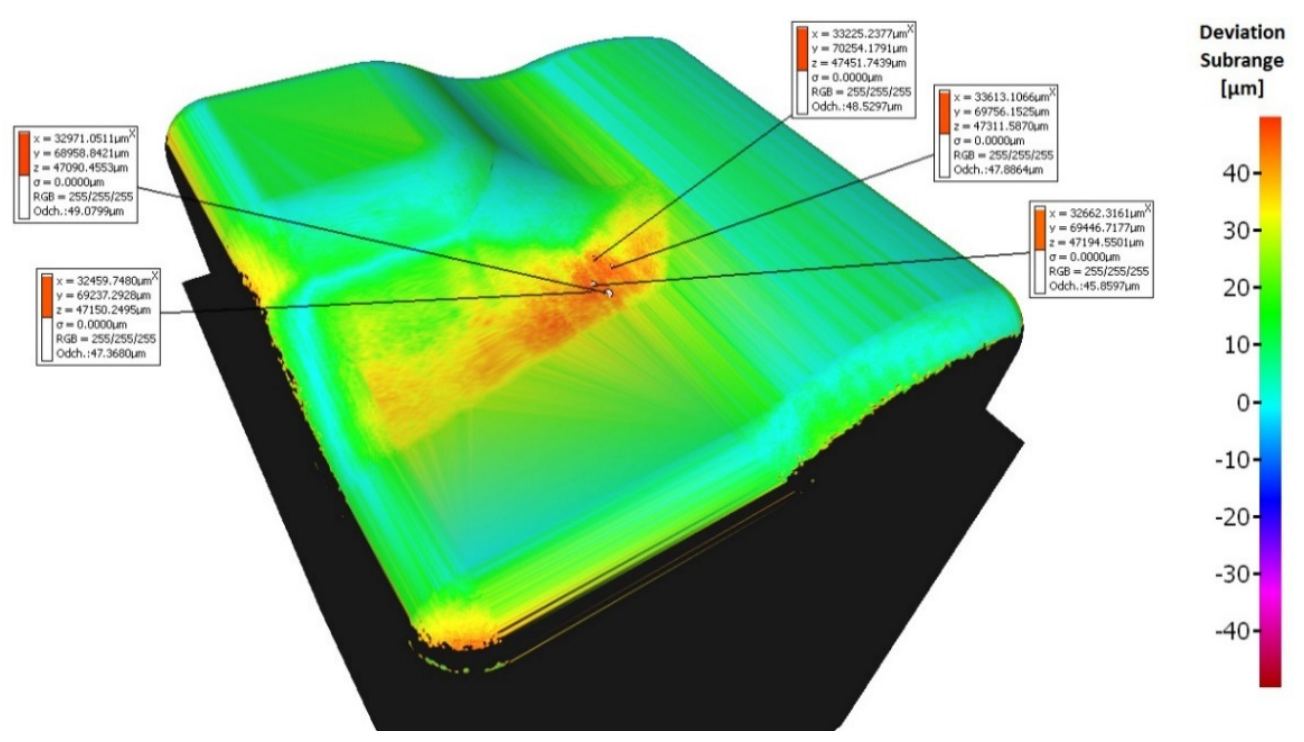

(b)

Figure 18. Comparison of predicted surfaces errors and real surface errors, $3+2$-axis milling, tool inclination $\beta_{\mathrm{f}}=15^{\circ}, \beta_{\mathrm{n}}=5^{\circ}$, (a) predicted errors and (b) real surface errors.

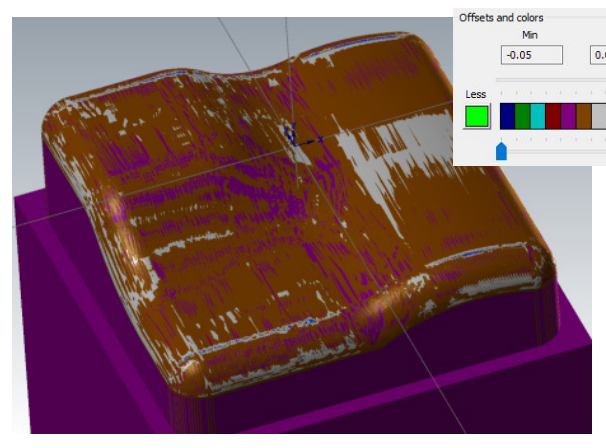

(a)

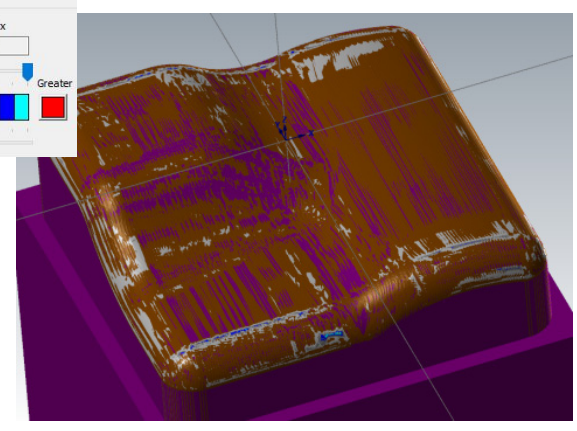

(b)

Figure 19. Comparison of the CAD model (Inventor) and the prediction of milled surface errors using 5-axis milling (Mastercam), (a) tool inclination $\beta_{\mathrm{f}}=5^{\circ}, \beta_{\mathrm{n}}=10^{\circ}$ and (b) tool inclination $\beta_{\mathrm{f}}=10^{\circ}$, $\beta_{\mathrm{n}}=10^{\circ}$ ). 


\subsection{Surface Roughness Measurement}

Surface roughness was measured only in problematic areas in the center of the sample, see Figure 9.

Measurement has been performed according the standard ISO 25178-1 [26] and ISO 25178-2 [27]. Filtration L-filter Lc (cut off) has been set according the standards with filter $\lambda \mathrm{c}=800 \mu \mathrm{m}$.

Tables 3 and 4 show maximum deviation and selected surface roughness parameters in the center area of samples (Sa-Arithmetical mean height of the scale-limited surface, Sp-Maximum peak height of the scale-limited surface, Sz-Maximum height of the scalelimited surface, and Vmp-Peak material volume of the scale-limited surface). Parameter Vmp is one of many volume parameters of surface roughness and gives better knowledge about the quality of the rated surface. It can be clearly seen in Table 4 . Where green are positive results and red negative results. A darker green color means better positive results. A darker red color indicates worse negative results. The results of the previous author's studies show that the surface roughness is influenced by the inclination of the tool $[2,14,21]$. Surface roughness can affect accuracy [28-36]. Selected roughness parameters compare the peaks that can affect geometric accuracy.

Better surface roughness was achieved with $3+2$-axis milling. Selected surface roughness parameters show a lower range of values (max. value-min. value) during $3+2$-axis machining. $3+2$-axis has better results than 5 -axis. However, the values of the surface roughness are very similar. Within the extended uncertainty of measurement, values are close to each other, in particular the parameter Sa $( \pm 0.15 \mu \mathrm{m}$ and $\pm 0.51 \mu \mathrm{m})$.

Figure 20 shows the advantages of the tilting tools for achieving an improved machined surface. Stable and best results have inclination $\beta_{\mathrm{f}}=15^{\circ}$ in the range from $\beta_{\mathrm{n}}=10$ to $20^{\circ}$ during $3+2$-axis milling.

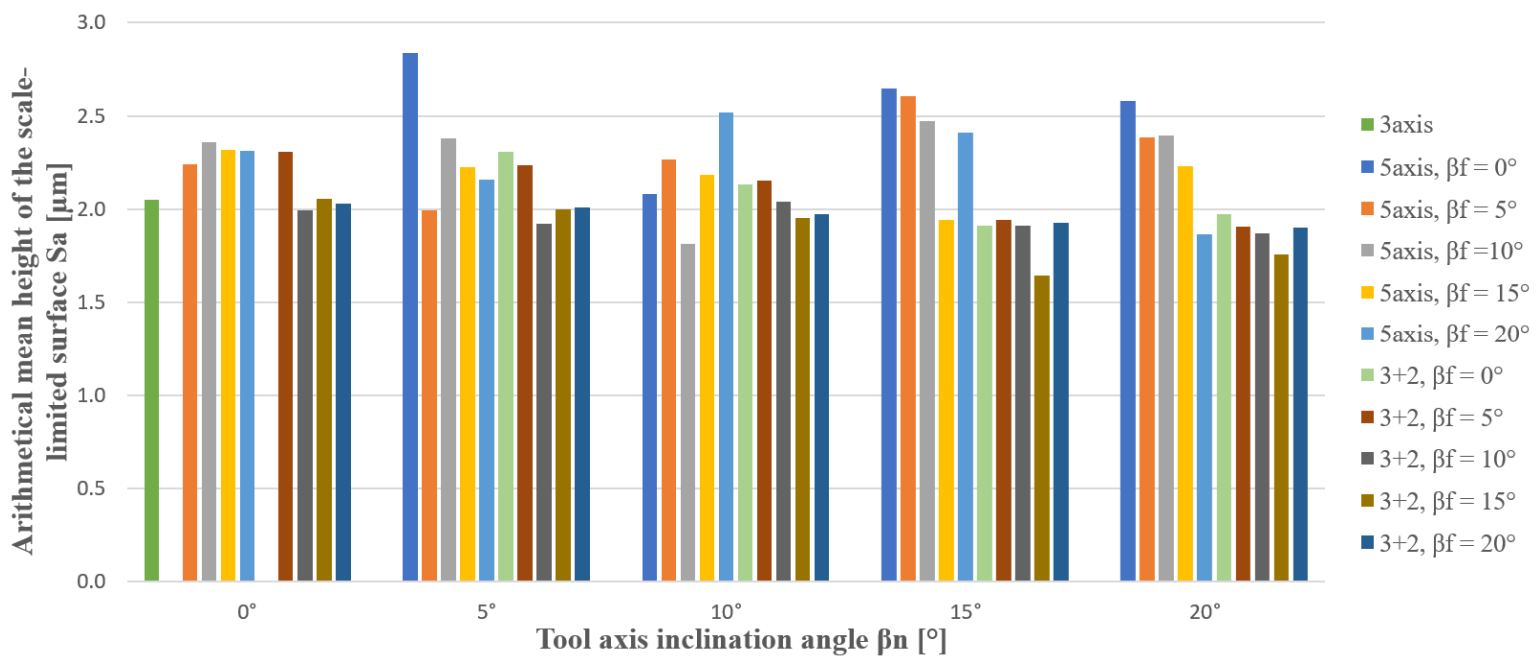

Figure 20. Surface roughness (Sa-Arithmetical mean height of the scale-limited surface) dependence on tool axis inclination angle.

Table 3. Maximum deviation and surface roughness during 3-axis machining.

\begin{tabular}{cccccc}
\hline Inclination Angle & Max. Deviation & \multicolumn{4}{c}{ Surface Roughness } \\
\hline$\beta_{\mathbf{f}}, \beta_{\mathbf{n}}$ & & Sa & Sp & Sz & Vmp \\
\hline$\left[{ }^{\circ}\right]$ & {$[\mu \mathrm{m}]$} & {$[\mu \mathrm{m}]$} & {$[\mu \mathrm{m}]$} & {$[\mu \mathrm{m}]$} & {$\left[\mathrm{mL} \cdot \mathrm{m}^{-2}\right]$} \\
\hline $0^{\circ} 0^{\circ}$ & 42 & 2.05 & 13.06 & 25.72 & 0.148 \\
\hline Extended uncertainty & 3.38 & 0.11 & 1.00 & 2.41 & 0.081 \\
\hline
\end{tabular}


Table 4. Maximum deviation and surface roughness during $3+2$-axis and 5-axis machining (where green are positive results and red negative results).

\begin{tabular}{|c|c|c|c|c|c|c|c|c|c|c|}
\hline \multirow[b]{2}{*}{$\begin{array}{c}\text { Inclination } \\
\text { Angle } \\
\beta_{\mathrm{f}}, \beta_{\mathrm{n}}\end{array}$} & \multicolumn{2}{|c|}{ Max. Deviation } & \multicolumn{8}{|c|}{ Surface Roughness } \\
\hline & $\begin{array}{l}3+2 \\
\text {-axis }\end{array}$ & 5 -axis & $\begin{array}{c}3+2 \\
\text {-axis } \\
\text { Sa }\end{array}$ & $\begin{array}{c}5- \\
\text { axis } \\
\text { Sa }\end{array}$ & $\begin{array}{c}3+2 \\
\text {-axis } \\
S p\end{array}$ & $\begin{array}{c}5- \\
\text { axis } \\
\text { Sp }\end{array}$ & $\begin{array}{c}3+2 \\
\text {-axis } \\
\text { Sz }\end{array}$ & $\begin{array}{c}5- \\
\text { axis } \\
\text { Sz }\end{array}$ & $\begin{array}{l}3+2 \\
\text {-axis } \\
\text { Vmp }\end{array}$ & $\begin{array}{l}\text { 5-axis } \\
\text { Vmp }\end{array}$ \\
\hline$\left[{ }^{\circ}\right]$ & {$[\mu \mathrm{m}]$} & {$[\mu \mathrm{m}]$} & {$[\mu \mathrm{m}]$} & {$[\mu \mathrm{m}]$} & {$[\mu \mathrm{m}]$} & {$[\mu \mathrm{m}]$} & {$[\mu \mathrm{m}]$} & {$[\mu \mathrm{m}]$} & {$\left[\mathrm{mL} \cdot \mathrm{m}^{-2}\right]$} & {$\left[\mathrm{mL} \cdot \mathrm{m}^{-2}\right]$} \\
\hline $0^{\circ}, 5^{\circ}$ & 38 & 14 & 2.31 & 2.84 & 22.64 & 18.56 & 38.24 & 46.95 & 0.159 & 0.193 \\
\hline $0^{\circ}, 10^{\circ}$ & 42 & 18 & 2.13 & 2.08 & 19.81 & 21.39 & 35.74 & 37.93 & 0.160 & 0.139 \\
\hline $0^{\circ}, 15^{\circ}$ & 47 & 12 & 1.91 & 2.65 & 11.06 & 34.50 & 25.40 & 59.81 & 0.122 & 0.190 \\
\hline $0^{\circ}, 20^{\circ}$ & 45 & 12 & 1.98 & 2.58 & 18.45 & 22.79 & 37.16 & 44.43 & 0.125 & 0.175 \\
\hline $5^{\circ}, 0^{\circ}$ & 38 & 19 & 2.31 & 2.24 & 22.64 & 15.65 & 40.96 & 28.22 & 0.192 & 0.139 \\
\hline $5^{\circ}, 5^{\circ}$ & 50 & 5 & 2.24 & 1.99 & 17.96 & 18.82 & 41.57 & 38.13 & 0.154 & 0.158 \\
\hline $5^{\circ}, 10^{\circ}$ & 49 & 10 & 2.15 & 2.27 & 15.07 & 15.64 & 33.83 & 29.71 & 0.145 & 0.165 \\
\hline $5^{\circ}, 15^{\circ}$ & 52 & 15 & 1.94 & 2.61 & 12.58 & 22.52 & 35.57 & 46.85 & 0.122 & 0.180 \\
\hline $5^{\circ}, 20^{\circ}$ & 51 & 10 & 1.91 & 2.38 & 17.34 & 14.08 & 40.41 & 29.26 & 0.126 & 0.147 \\
\hline $10^{\circ}, 0^{\circ}$ & 43 & 15 & 2.00 & 2.36 & 18.37 & 15.37 & 40.41 & 31.87 & 0.160 & 0.155 \\
\hline $10^{\circ}, 5^{\circ}$ & 52 & 20 & 1.93 & 2.38 & 13.87 & 26.77 & 31.64 & 44.77 & 0.140 & 0.167 \\
\hline $10^{\circ}, 10^{\circ}$ & 53 & 10 & 2.04 & 1.82 & 15.04 & 16.71 & 39.57 & 30.27 & 0.150 & 0.130 \\
\hline $10^{\circ}, 15^{\circ}$ & 55 & 21 & 1.91 & 2.47 & 16.62 & 19.73 & 35.67 & 39.22 & 0.127 & 0.160 \\
\hline $10^{\circ}, 20^{\circ}$ & 56 & 25 & 1.87 & 2.40 & 17.36 & 15.55 & 32.81 & 35.32 & 0.113 & 0.174 \\
\hline $15^{\circ}, 0^{\circ}$ & 42 & 19 & 2.06 & 2.32 & 14.61 & 26.24 & 29.05 & 38.80 & 0.150 & 0.149 \\
\hline $15^{\circ}, 5^{\circ}$ & 48 & 24 & 2.00 & 2.23 & 12.88 & 16.18 & 28.00 & 36.16 & 0.125 & 0.158 \\
\hline $15^{\circ}, 10^{\circ}$ & 46 & 29 & 1.95 & 2.18 & 15.24 & 15.02 & 33.26 & 28.75 & 0.129 & 0.151 \\
\hline $15^{\circ}, 15^{\circ}$ & 56 & 9 & 1.64 & 1.94 & 9.88 & 14.41 & 21.65 & 27.14 & 0.093 & 0.118 \\
\hline $15^{\circ}, 20^{\circ}$ & 43 & 24 & 1.76 & 2.23 & 12.31 & 13.85 & 23.54 & 31.17 & 0.100 & 0.145 \\
\hline $20^{\circ}, 0^{\circ}$ & 20 & 31 & 2.03 & 2.31 & 15.41 & 15.91 & 30.67 & 31.57 & 0.127 & 0.151 \\
\hline $20^{\circ}, 5^{\circ}$ & 46 & 28 & 2.01 & 2.16 & 21.68 & 19.94 & 42.57 & 34.83 & 0.157 & 0.140 \\
\hline $20^{\circ}, 10^{\circ}$ & 53 & 27 & 1.97 & 2.52 & 16.07 & 34.46 & 33.81 & 54.73 & 0.151 & 0.193 \\
\hline $20^{\circ}, 15^{\circ}$ & 51 & 32 & 1.93 & 2.41 & 13.83 & 17.39 & 28.24 & 32.13 & 0.139 & 0.158 \\
\hline $20^{\circ}, 20^{\circ}$ & 52 & 10 & 1.90 & 1.86 & 12.05 & 11.64 & 30.85 & 23.94 & 0.109 & 0.112 \\
\hline $\begin{array}{l}\text { Range of } \\
\text { values }\end{array}$ & $\begin{array}{l}0 \text { to } \\
56\end{array}$ & 0 to 32 & 0.67 & 1.02 & 12.77 & 22.86 & 20.92 & 35.87 & 0.099 & 0.081 \\
\hline $\begin{array}{l}\text { Arithmetic } \\
\text { mean }\end{array}$ & 47 & 18 & 1.99 & 2.30 & 15.95 & 19.30 & 33.78 & 36.75 & 0.136 & 0.156 \\
\hline $\begin{array}{l}\text { Extended } \\
\text { uncertainty }\end{array}$ & 15.68 & 15.69 & 0.32 & 0.51 & 7.01 & 12.10 & 11.75 & 17.97 & 0.083 & 0.082 \\
\hline
\end{tabular}

\section{Discussion and Conclusions}

It can be concluded that the tool inclination has an influence on the accuracy of machining after the final experiment evaluation. This paper shows that using different milling strategies during the ball-end milling finishing of free-form surfaces has an effect on accuracy and surface errors. When comparing machining accuracy during 3-axis, $3+2$-axis, and 5-axis milling (under the same conditions-the same cutting conditions (the same $\mathrm{f}_{\mathrm{z}}$, $\mathrm{v}_{\mathrm{c}}, \mathrm{a}_{\mathrm{p}}, \mathrm{a}_{\mathrm{e}}$, etc., see Table 2), the highest accuracy was achieved with 5-axis simultaneous milling ( $\beta_{\mathrm{f}}=10$ to $15^{\circ}, \beta_{\mathrm{n}}=10$ to $15^{\circ}$, deviation range from 0 to $\left.17 \mu \mathrm{m}\right)$. Inaccuracies were found mostly at problematic areas of the center in 3 -axis and $3+2$-axis milling (deviations range from 0 to $56 \mu \mathrm{m}$ ), see Table 4 . The arithmetic mean of inaccuracies in the 5 -axis machining is $18 \mu \mathrm{m}$ and in the $3+2$-axis machining is $47 \mu \mathrm{m}$.

The prediction (calculation) of residual material in the CAM system for a group of samples machined by 5-axis milling is the most consistent with the real-measured residual material. The results show the quality of the computational algorithm used in the CAM module of 5-axis milling.

It is beneficial to use tool axis inclination angle in the tool feed direction and avoid inclination $\beta_{\mathrm{f}}=0^{\circ}$, where are surface roughness parameters $\mathrm{Vmp}$ and $\mathrm{Sz}, \mathrm{Sp}$ highest. Where in the axis the material is pushed not cut, the effective cutting speed is $0 \mathrm{~m} \cdot \mathrm{min}^{-1}$. We recommend using tool axis inclination angle in the interval $\beta_{\mathrm{f}}=15$ to $20^{\circ}, \beta_{\mathrm{n}}=5$ to $20^{\circ}$. $3+2$-axis milling shows more stable values (lower range of values) of surface roughness than 5-axis simultaneous milling. Free-form finishing milling with a targeted tool axis inclination angle can improve surface roughness or can replace the grinding operation, i.e., the manual finishing grinding operation of free-form surfaces. 
Author Contributions: Conceptualization, M.S.; methodology, M.S., M.Š. and Z.P.; software, M.S. and Z.P.; validation, L.Č.; formal analysis, L.Č.; investigation, M.S. and Z.P.; resources, L.Č.; data curation, M.Š.; writing-original draft preparation, M.S.; writing-review and editing, M.S. All authors have read and agreed to the published version of the manuscript.

Funding: This research was funded by project Innovative and additive manufacturing technologynew technological solutions for 3D printing of metals and composite materials, reg. no. CZ.02.1.01/0.0 /0.0/17_049/0008407 financed by Structural and Investment Founds of Europe Union.

Institutional Review Board Statement: Not applicable.

Informed Consent Statement: Not applicable.

Data Availability Statement: The data presented in this study are available on request from the corresponding author.

Conflicts of Interest: The authors declare no conflict of interest. The funders had no role in the design of the study; in the collection, analyses, or interpretation of data; in the writing of the manuscript, or in the decision to publish the results.

\section{References}

1. Yüncüoğlu, E.U.; Bağci, E. The Effects of Milling Strategies on Forces, Material Removal Rate, Tool Deflection, and Surface Errors for the Rough Machining of Complex Surfaces. J. Mech. Eng. 2017, 63, 643-656. [CrossRef]

2. Sadílek, M. Výzkum Změny Polohy Osy Nástroje Při Víceosém Frézování/Research of Position Tool Change in Multi-Axis Milling; Habilitation Work; VSB-Technical University of Ostrava, Faculty of Mechanical Engineering: Ostrava, Czech Republic, 2012; p. 150, app. 1.3.

3. Bouzakis, K.-D.; Aichouh, P.; Efstathiou, K. Determination of the chip geometry, cutting force and roughness in free form surfaces finishing milling, with ball end tools. Int. J. Mach. Tools Manuf. 2003, 43, 499-514. [CrossRef]

4. Kua, B.W.; Tanaka, H.; Obata, F.; Sakamoto, S. Prediction of cutting forces and machining error in ball end milling of curved surfaces-I theoretical analysis. Precis. Eng. 2001, 25, 266-273. [CrossRef]

5. Imani, B.M.; Sadeghi, M.; Elbestawi, M. An improved process simulation system for ball-end milling of sculptured surfaces. Int. J. Mach. Tools Manuf. 1998, 38, 1089-1107. [CrossRef]

6. Kim, G.M.; Chu, C.N. Mean cutting force prediction in ball-end milling using force map method. J. Mater. Process. Technol. 2004, 146, 303-310. [CrossRef]

7. Kim, G.; Cho, P.; Chu, C.N. Cutting force prediction of sculptured surface ball-end milling using Z-map. Int. J. Mach. Tools Manuf. 2000, 40, 277-291. [CrossRef]

8. Schulz, H.; Hock, S. High-Speed Milling of Dies and Moulds-Cutting Conditions and Technology. CIRP Ann. 1995, 44, 35-38. [CrossRef]

9. Ko, T.J.; Kim, H.S.; Lee, S.S. Selection of the Machining Inclination Angle in High-Speed Ball End Milling. Int. J. Adv. Manuf. Technol. 2001, 17, 163-170. [CrossRef]

10. Mizugaki, Y.; Hao, M.; Kikkawa, K.; Nakagawa, T. Geometric Generating Mechanism of Machined Surface by Ball-nosed End Milling. CIRP Ann. 2001, 50, 69-72. [CrossRef]

11. Mizugaki, Y.; Kikkawa, K.; Terai, H.; Hao, M.; Sata, T. Theoretical Estimation of Machined Surface Profile Based on Cutting Edge Movement and Tool Orientation in Ball-nosed End Milling. CIRP Ann. 2003, 52, 49-52. [CrossRef]

12. Toh, C. Surface topography analysis in high speed finish milling inclined hardened steel. Precis. Eng. 2004, 28, 386-398. [CrossRef]

13. Kim, G.; Kim, B.; Chu, C. Estimation of cutter deflection and form error in ball-end milling processes. Int. J. Mach. Tools Manuf. 2003, 43, 917-924. [CrossRef]

14. Sadílek, M.; Cep, R.; Budak, I.; Soković, M. Aspects of Using Tool Axis Inclination Angle. Stroj. Vestn. 2011, 57, 681-688. [CrossRef]

15. Lee, C.M.; Kim, S.W.; Lee, Y.H.; Lee, D.W. The optimal cutter orientation in ball end milling of cantilever-shaped thin plate. J. Mater. Process. Technol. 2004, 153, 900-906. [CrossRef]

16. Krolczyk, G.; Gajek, M.; Legutko, S. Predicting the tool life in the dry machining of duplex stainless steel. Eksploat. $i$ Niezawodn. Maint. Reliab. 2013, 15, 62-65.

17. Królczyk, G.; Legutko, S.; Stoić, A. Influence of cutting parameters and conditions onto surface hardness of duplex stainless steel after turning process. Teh. Vjesn. Tech. Gaz. 2013, 20, 1077-1080.

18. Kita, Y.; Furuike, H.; Kakino, Y.; Nakagawa, H.; Hirogaki, T. Basic study of ball end milling on hardened steel. J. Mater. Process. Technol. 2001, 111, 240-243. [CrossRef]

19. Lim, E.M.; Menq, C.-H. Integrated planning for precision machining of complex surfaces. Part 1: Cutting-path and feedrate optimization. Int. J. Mach. Tools Manuf. 1997, 37, 61-75. [CrossRef]

20. Wei, Z.C.; Wang, M.J.; Cai, Y.J.; Zhu, J.N.; Wang, L. Form error estimation in ball-end milling of sculptured surface with z-level contouring tool path. Int. J. Adv. Manuf. Technol. 2012, 65, 363-369. [CrossRef] 
21. Pagáč, M.; Malotová, Š.; Sadílek, M.; Petrů, J.; Zlámal, T.; Kratochvíl, J. Influence of effective milling strategies on the residual stress. In Proceedings of the Metal 2016: 25th Anniversary International Conference on Metallurgy and Materials, Brno, Czech Republic, 25-27 May 2016; pp. 819-824.

22. Sadílek, M.; Fojtík, F.; Sadílková, Z.; Kolařík, K.; Petrů, J. Study of Effects of Changing the Position of the Tool Axis to the Machined Surface. Trans. Famena 2015, 39, 33-46.

23. Sadílek, M.; Kousal, L.; Náprstková, N.; Szotkowski, T.; Hajnyš, J. The Analysis of Accuracy of Machined Surfaces and Surfaces Roughness after 3axis and 5axis Milling. Manuf. Technol. 2018, 18, 1015-1022. [CrossRef]

24. Zelinka, J.; Sadílek, M.; Szkandera, P.; Mizera, O.; Čepová, L. The Surface Roughness of The Machined Surface of Multiaxial Milling. In Proceedings of the Metal 2019 Conference Proeedings, Brno, Czech Republic, 22-24 May 2019; pp. 1197-1202.

25. Peterka, J. Nový přístup výpočtu střední aritmetické odchylky drsnosti obrobeného povrchu při kopírovacím frézováním/A new approach of calculating the arithmetical mean deviation of roughness of the machined surface at the free form surface milling. Strojírenská Technol. Manuf. Technol. 2004, 9, 28-32.

26. ISO 25178-1:2016. Geometrical Product Specifications (GPS)—Surface Texture: Areal_Part 1: Indication of Surface Texture; ISO: Geneve, Switzerland, 2016; p. 40, Classification character 014451.

27. EN ISO 25178-2:2012. Geometrical Product Specifications (GPS)—Surface Texture: Areal—Part 2: Terms, Definitions and Surface Texture Parameters; ISO: Geneve, Switzerland, 2012; p. 52, Classification character 014451.

28. Adamczak, S.; Miko, E.; Čuš, F. A model of surface roughness constitution in the metal cutting process applying tools with defined stereometry. Stroj. Vestn. J. Mech. Eng. 2009, 55, 45-54.

29. Čep, R.; Janásek, A.; Martinický, B.; Sadílek, M. Cutting tool life tests of ceramic inserts for car engine sleeves. Teh. Vjesn. Tech. Gaz. 2011, 18, 203-209.

30. Bujok, P.; Chistyakov, V.; Klempa, M.; Straupnik, I. Efficiency analyze Borehole Heat Exchangers (BHEs) of the research geothermal polygon placed at VŠB-Technical University of Ostrava. Renew. Energy Power Qual. J. 2012, 697-700. [CrossRef]

31. Chen, J.-S.; Huang, Y.-K.; Chen, M.-S. A study of the surface scallop generating mechanism in the ball-end milling process. Int. J. Mach. Tools Manuf. 2005, 45, 1077-1084. [CrossRef]

32. Ungureanu, N.S. Fiabilitatea si Diagnoza / Reliability and Diagnosis; Editura Risoprint: Cluj Napoca, Romania, 2003.

33. Čep, R.; Janásek, A.; Čepová, L.; Petrů, J.; Hlavatý, I.; Car, Z.; Hatala, M. Experimental testing of exchangeable cutting inserts cutting ability / Eksperimentalno ispitivanje rezne sposobnosti izmjenjivih reznih umetaka. Teh. Vjesn. Tech. Gaz. 2013, 20, 21-26.

34. Kurt, M.; Bagci, E. Feedrate optimisation/scheduling on sculptured surface machining: A comprehensive review, applications and future directions. Int. J. Adv. Manuf. Technol. 2011, 55, 1037-1067. [CrossRef]

35. Production, W. Chip Fragmentation in the Milling of AZ91HP Magnesium Alloy. Stroj. Vestn. 2017, 63, 628-642. [CrossRef]

36. Scandiffio, I.; Diniz, A.E.; De Souza, A.F. The influence of tool-surface contact on tool life and surface roughness when milling free-form geometries in hardened steel. Int. J. Adv. Manuf. Technol. 2017, 92, 615-626. [CrossRef] 